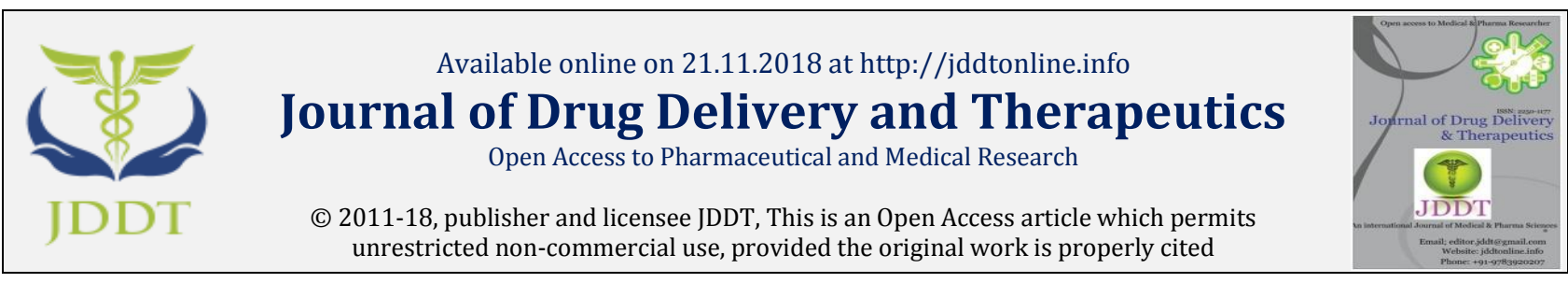

Open $\odot$ Access

Review Article

\title{
Management of Grahani Roga by Ayurveda principles and life style modification
}

\author{
Dr. Sapan Jain ${ }^{*}$, Dr. Seema G Chawardol², Dr. Jinesh Jain³ ${ }^{3}$, Dr. O.P Dwivedi \\ ${ }^{1}$ Professor \& HOD Department of Kayachikitsa, Jupiter Ayurveda Medical College, Nagpur, India. \\ 2Professor \& HOD Department of Panchkarma, Government Ayurveda College, Nanded, India. \\ ${ }^{3}$ HOD Department of Panchkarma, Government Ayurveda College, Rewa, India. \\ ${ }^{4}$ Professor \& HOD Department of Sharir Rachana, Government Ayurveda College, Rewa, India.
}

\begin{abstract}
Grahani is an ayurveda terms related to the seat of agni (digestive fire), which help in the metabolism and digestion of food. The ancient text of ayurveda described that ingestion, digestion, absorption and assimilation of Aahaar is regulated by Grahani. When this Agni becomes; mandagni then improper digestion of ingested food leads pathological condition termed as Grahani roga. Similarly Trividh anomalies of the Jatharagni also termed as Grahanidosha. Grahani is a disease which affects large population globally especially in developing country and associated with improper food habits along with stressful lifestyle. The pathogenesis of Grahani roga works around Agnidosha which associated with impaired digestive function of digestive fire. Ayurveda described various treatment modalities for the management of Grahani roga such as; use of herbs \& formulation, yoga and life style modification. Present article summarized ayurveda perspective of Grahani roga and its management by ayurveda principles and life style modification.
\end{abstract}

Keywords: Ayurveda, Grahani, Agnidosha, Yoga, Life style

Article Info: Received 05 Oct, 2018; Review Completed 06 Nov 2018; Accepted 14 Nov 2018; Available online 21 Nov 2018

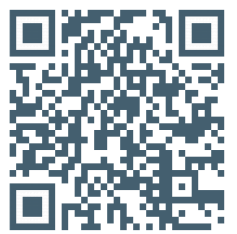

\section{Cite this article as:}

Jain S, Chawardol SG, Jain J, Dwivedi OP, Management of Grahani Roga by Ayurveda principles and life style modification, Journal of Drug Delivery and Therapeutics. 2018; 8(6):393-396

DOI: http://dx.doi.org/10.22270/jddt.v8i6.2061

Dr. Sapan Jain, Professor \& HOD Department of Kayachikitsa, Jupiter Ayurveda Medical College, Nagpur, India.

\section{INTRODUCTION}

Grahani Dosha is a common problem especially affects people living with unhygienic conditions and suffered with nutritional deficiency. The faulty lifestyle, consumption of junk food, stress, inadequate sleep and avoidance of Sadvritta are the major reasons of Grahani Dosha. Pathologically disease initiates due to the improper digestion of food which further vitiate Agni and Doshas leading to formation of ama which further resulted symptoms of constipation and diarrhea 1-4. Drugs having Kashaya Rasa, Ushna Veerya, Madhura Vipaka \& Ruksha Guna help to pacifies Vata \& Pitta Dosha therefore potentiates Agni which improves process of digestion. Drugs which gives bulk to the stool, hydrate body and possess nutritional benefits also relieve symptoms of Grahani Dosha. Ayurveda text emphasized on four types of Grahani Dosha as mentioned in Figure 1. This article described general consideration of Grahani Dosha and its management by ayurveda and conduction of disciplinary life style ${ }^{2-7}$.

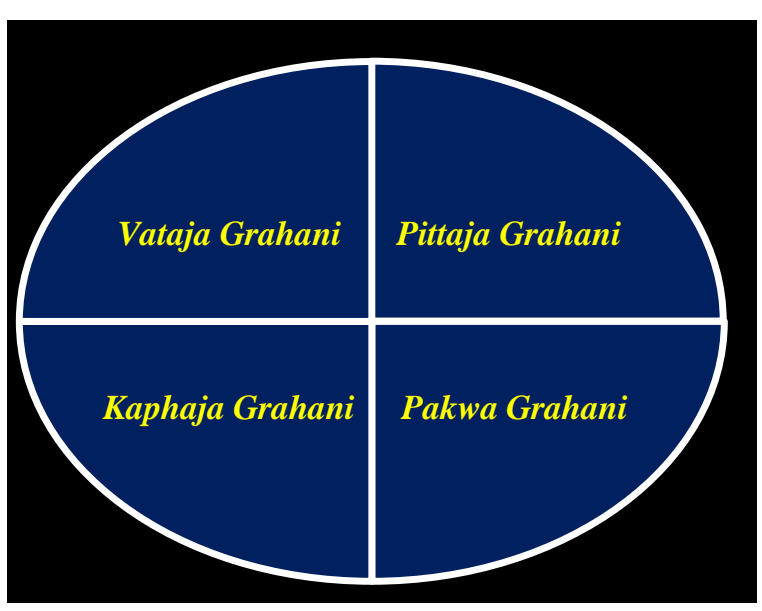

Figure 1: Types of Grahani Roga 


\section{Etiological Factors}

* Abhojanat, Ajeernabhojanat, Attibhojanaat, Visamasanat, Asatmya Guru, Ruksa and Sandusta Bhojanat etc.

* Vyadhikarshanat and Vegavidharana

* Stress, anxiety and grief

* In disciplinary life style and bad food habits

* Unhygienic environmental condition

* Nutritional insufficiency

* Contagious predominance

* Improper functioning of digestive fire

* Diseased condition which weakened Agni

* Virudha-ahara

* Avoidance of concept of Desha and kala during consumption of food stuffs

- Excessive use of antibiotics.

\section{Symptoms}

According to Acharaya the predominant symptoms of disease are; Aalasya, Trishna, Aanvidaah, Chir Pakka, Balakshaya and Gaurvam, etc. Other symptoms of diseases are Aruchi, Kasa, Karnakshveda and Antrakunjana. Intestinal spasms, diarrhea, constipation and abdominal pain also observed in acute condition 6-8.

\section{AYURVEDA MANAGEMENT OF GRAHANI DOSHA}

$>$ The traditional text of ayurveda suggested that Grahani Dosha may be treated by following concept of Langhana and using Deepana and Pachana medicines which help to potentiate Agni and eliminate $a m a$.

> Purgation therapy with stimulant drugs also helps to remove $A m a$

$>$ Husk of Ashvagol help in evacuation of stool.

$>$ Butter milk (Takra) also suggested by ancient Acharya for treatment of Grahani.

Table 1: Specific ayurveda treatment for Grahaniroga

\begin{tabular}{|cll|}
\hline S. No. & \multicolumn{1}{c|}{ Treatment } & \multicolumn{1}{c|}{ Beneficial effects } \\
\hline $\mathbf{1}$ & Niruhavasti, Virechana and Anuvasanvasti & Remove symptoms of Vatajagrahani \\
\hline $\mathbf{2}$ & Chandanadya ghritam, Tikataghrita & Pacifies Pittajagrahani \\
\hline $\mathbf{3}$ & Pippalyadya choorna & Treat Kaphajagrahani \\
\hline $\mathbf{4}$ & Nagaradi kwatha & Pacifies vitiated Vata thus help in Vatajagrahani \\
\hline $\mathbf{5}$ & Madhukasava, Duralabhasava, & Relieve Kaphajagrahani \\
\hline $\mathbf{6}$ & Panhchmuladya Taila & Help to manage Vatajagrahani \\
\hline $\mathbf{7}$ & HaridradyaKshara, Duralabhadyakshara & Treat Kaphajagrahani \\
\hline $\mathbf{8}$ & Abhayadi kashaya & Suggested for Vatajagrahani \\
\hline
\end{tabular}

\section{LIFE STYLE MODIFICATION IN GRAHANI}

Modification in life style and balanced diet regime along with consideration of Pathya Apathya help to cure Grahani.

\section{Diet modification}

$>$ Modification in diet pattern towards the healthy eating habits boosts Agni and prevents chances of Grahani.

$>$ Meal should be consumed at regular intervals.

$>$ Junk foods, allergic foods and food difficult to digest should be avoided.

$>$ Ayurveda mentioned balanced diet under Sansarjana Krama with routine diet plan depending on the Prakriti of the individual. Thus patient of Grahani recomeded to follow diet pattern of Sansarjana Krama.

$>$ One should avoid Abhojanat, Ajeernabhojanat, Attibhojanaat, Visamasanat, Asatmya and Sandusta Bhojanat etc

$>$ Preparation and consumption of unhygienic food articles.

$>$ Diet containing balanced nutritional value need to be adopted.

$>$ Virudha-ahara must be avoided; means one should consume diet as per his/her internal constitution by following concept of Desha and Kala.

Dietary materials recommended for Grahani roga are as follows:

$>$ Diets which promote digestive enzyme; restore normal flora and maintain nutritional sufficiency should be adopted such as; fibers, fruit, vegetables, grains and curd.

> Yavagu, Panchkola soup

$>$ Takrarista, Jangalmansa

$>$ Vegetable soups

$>$ Light diet and Soup of dried radish

\section{Behavior modification}

$>$ Behavioral factors such as fear, grief, stress and sleeplessness may also lead symptoms of Grahani. Therefore one should avoid stress, fear and grief to disrupt condition of depression which may affect Agni.

$>$ One should remain positive and enthusiastic to maintain normal metabolic functioning.

$>$ Habits of too much thinking/Chintan should be avoided which may affect process of digestion since during thinking process bold circulation remain associated with brain mainly instead of intestine.

$>$ One should always think that the food which he/she going to consume will offers good effect.

$>$ Be happy and associated with mental empowerment activities.

$>$ One should consume diet by following rules of Swasthwarita in proper manner so to achieve maximum beneficial effect of consumed food ${ }^{7-9}$.

\section{Daily regimen modification/Exercise and yoga}

* In disciplinary life style need to be avoided.

* Day time sleeping and late night awakening should be avoided. 
* One should follow daily regimen with fix timing of each and every activities including fix daily routine of exercise, breakfast, meal and sleep.

* Regular exercise to strengthen body \& Agni.

* Mediation to calm down stress.

* Yoga and Pranayama also offers beneficial effect to increase stress resistance.

* Ayurveda mentioned some defined regimen such as; Ritucharya and Dinacharya to get beneficial results of daily regimen.

* Dhyan and Shodhna procedure after some fix interval also offers beneficial effect in Grahani 7-10.

\section{Role of Asana in Grahani}

Bhujangasana: Bhujangasana heat the body and improves digestion.

Mayurasana: Mayurasana removes undigested material in stomach.

\section{REFERENCES}

1. Tripathi Brahmanand and Pandey G.S, Charaka Samhita of Agnivesa with Charaka Chandrika Hindi Commentory, 6th Ed., Varanasi: Chaukhamba Surbharati Prakashan., (Vol-1), 1999.

2. Shastri K. Ambikadatta, Sushruta Samhita of Maharsi Sushrut edited with Ayurveda Tattva Sandipika Hindi Commentary, 13th Ed., Varanasi: Chaukhamba Sanskrit Bhawan., (Vol-2), 2000.

3. Vridda Jeevaka- Kashyapa Samhita (Vriddajeevaka Tantra) by -Sharma Hemaraj Pandit (Nepal Rajguru) revised by Vatsya with Sanskrit introduction and Vidyothini Hindi Commentary, Varanasi: Chaukhamba Sanskrit Sansthan.,1994.

4. Rama Valamba Shashtri, Harita Samhita Edited with Asha Hindi Commentary, Varanasi: Prachya Prakashan., 1985.

5. Kashinath Shastri; Charak Samhita; Chikitsa Sthanam, chapter 15, verse no 51-52; Chaukhambha Bharati Academy; Varanasi; $2011 ; 461$
Paschimottanasana: Paschimottanasana boosts gastric fire. Matsyendrasana: Matsyendrasana stimulates jatharagni.

Sarvangasana: Sarvangasana pacifies Kapha \& Pitta, also relief indigestion.

\section{CONCLUSION}

Grahani is disease of Annavaha srotas related to Agni and life style pattern. Ayurveda considers Grahani as Tridoshatmaka disease of digestive fire occurs due to the vitiation of Agni; Jatharagni, Saman Vayu, Pachak Pitta and Kledaka Kapha. Disease characterized by abdominal pain, bloating and disturbed bowel habits. Ayurveda offers wide range of formulations and therapeutic modalities along with suggestions to modify life style pattern which overall offers beneficial effects in the management of Grahani roga.

6. Kaviraj Ambikadatta Shastri; Sushrut Samhita; Sutrasthana, chapter 15, verse no.48; Chaukhambha Sanskrit Sansthan; Varanasi; 2011; 64

7. Vaidya Yadavaji Trikamji. Charaka Samhita with Ayurveda Dipika Commentary of Chakrapanidatta, (Chikitsa Sthana 15, Verse 12) Varanasi; Chaukhambha Prakashan ; p. 513.

8. Kaviraja Ambikadutta Shastri. Susruta Samhita of Maharishi Sushruta, Part -II (Uttaratantra 40, Verse 167). Varanasi; Chaukhamba Sanskriti Sansthan; 2008. p. 237

9. Kaviraja Ambikadutta Shastri. Susruta Samhita of Maharishi Sushruta, Part -II (Uttaratantra 40, Verse 167). Varanasi; Chaukhamba Sanskriti Sansthan; 2008. p. 237.

10. Kaviraja Ambikadutta Shastri. Susruta Samhita of Maharishi Sushruta, Part -II (Uttaratantra 40, Verse 172). Varanasi; Chaukhamba Sanskriti Sansthan; 2008. p. 239. 